\title{
FAR FROM THE CITY LIGHTS: ENGLISH READING PERFORMANCE OF ESL LEARNERS IN DIFFERENT TYPES OF RURAL PRIMARY SCHOOL
}

EM Lemmer \& TV Manyike

University of South Africa

In this paper, the findings of a research study, in which the English reading performances of Grade 7 English Second Language (ESL) learners in four different types of rural primary school which use English as the language of learning and teaching (LoLT) were observed, are examined and how poor scores can be partly explained by the social context of learners and schools is explored. Although the Language in Education Policy in South Africa seeks to distribute and maintain the linguistic capital of the official languages through its support of multilingualism, the predominant preference for English as the LoLT in schooling disadvantages most ESL learners and perpetuates inequality in learner outcomes. This situation is exacerbated in certain school contexts such as those in rural settings. Bourdieu's theory of linguistic capital and Coleman's distinction between school social capital and home social capital are used as theoretical frameworks to the empirical inquiry undertaken in this study. The findings indicate a difference in the grammar and comprehension scores of learners in the respective participating schools as well as a sharp difference in the performance of learners in the different types of school involved. This suggests the current use of English as the LoLT does not mean that linguistic capital is equally distributed throughout schools. School type can thus act as an agent of cultural reproduction which influences learner outcomes.

\section{Key words}

Linguistic capital, social capital theories, English as the LoLT, rural schools, standardised testing, English reading performance, ESL Grade 7 learners.

\section{INTRODUCTION}

Language is a crucial means of gaining access to important knowledge and skills. In multilingual societies, language proficiency in the medium of instruction used in the schooling system exerts a powerful influence on the outcomes of schooling and, thus, life outcomes (Ovando \& McClaren, 1999:2). Social and economic privilege is partly constructed on the basis of the languages people know and, conversely, on the basis of the languages they do not know, that is, the linguistic capital that they possess or lack (Skatnubb-Kangas 2006: 2577). Attempts to distribute and maintain linguistic capital equitably in South Africa have been made through legislation dealing with language rights in general and language in education legislation in particular. Firstly, the Constitution of the Republic of South Africa (RSA 1996a) grants equal status to the country's eleven languages as official languages. Secondly, Section 6(1) of the South African School Act (SASA), 84 of 1996 (RSA 1996b) outlaws school admission on the basis of linguistic competence in a particular language and 
devolves the responsibility for determining a school language policy to parental choice via the school governing body. Finally, among other provisions, the Language in Education Policy (LiEP) (1997:106) promotes additive multilingualism through the following strategy of implementation: All learners should reach high levels of proficiency in at least two languages - their home language (L1) and one additional official language. Competency in the additional language (L2) should be acquired while the home language is maintained and developed.

In spite of this enabling legislative environment, many questions regarding the delivery of equitable literacy outcomes for all South African learners have been raised during the 15 years of educational transformation since 1994. Instead of the desired even distribution of linguistic capital among learners of all backgrounds, a clear language hierarchy has emerged, with English at the top, particularly as the preferred language of learning and teaching (LoLT) in schooling, irrespective of school context (Ornan, 2008:94). Thus, mastery of English has become a predicator of social prestige and wealth in South African society for those proficient in English, simultaneously excluding those who are not as proficient from similar advantages. In particular, English proficiency or lack thereof is a powerful determinant of persistent inequalities in learner outcomes in South African schools (Howie, 2008). In this vein, Fishman (1997:198) argued that learner competency in LoLT is inextricably linked to social attributes, such as socio-economic status; consequently, a schooling system that offers standard English as its LoLT services children from advantaged homes while challenging children from disadvantaged homes where the home language differs from the LoLT. Fishman's (1997) observation has been frequently demonstrated by the poor performance of South African primary school learners in literacy skills in international surveys, (International Association for the Evaluation of Educational Achievement, 2006; Moloi \& Strauss, 2005) and national benchmarking projects (Department of Basic Education, 2010). In particular, these assessments have indicated a large gap between the performance of urban and rural learners and between those whose LoLT is the same as their home language and those for whom the LoLT is different (Christie, 2008:147). Against this background, a considerable body of literature has been built up on research to investigate the impact of English as LoLT on ESL learners in South African schools. This research has typically drawn on second language acquisition (SLA) theories, which are mainly concerned with the cognitive and linguistic processes involved (Heugh 2000, 2002, 2005, 2008; MacDonald, 1990, 1991). Fewer researchers have endeavoured to explain differences in the language development of South African children in the social context of learning (MacDonald. 2006).

In light of this, the English reading performance of Grade 7 ESL learners in three different types of school in a predominantly rural setting was examined against the background of social theory, using standardised testing. The theoretical perspective used is an attempt to introduce a hitherto little-used dimension to the debate about the language proficiency of ESL learners and school achievement.

\section{Theoretical framework}

This article draws on Bourdieu's (1973, 1986, 1991) analysis of capital and social reproduction, with specific reference to linguistic capital as a component of cultural capital. This is followed by a brief overview of Coleman's $(1987,1995)$ work on school capital and home capital and other related studies. 
The broad theoretical background to this study is provided by Bourdieu's (1973) explanation of differences in children's school outcomes in France during the 1960s on the grounds of different forms of capital. Bourdieu (1986) is well known for his distinction between economic capital, that is, command over economic resources, social capital, which he famously defined as 'the aggregate of the actual or potential resources which are linked to possession of a durable network of more or less institutionalised relationships of mutual acquaintance and recognition' (Bourdieu, 1986: 245), and cultural capital, that is, attributes acquired by people mainly through membership of a social class or group and involving informal parental transmission of knowledge, skills and attitudes to children in the home. Less widely used is Bourdieu's (1973:71) identification of linguistic capital as an aspect or component of embodied cultural capital. Bourdieu (1973) pointed out that not only is access to the grammar of a language at the core of linguistic capital but also access to language use, that is, the competence to communicate and represent oneself in a given social context. People who have access to a particular linguistic environment through membership of a particular social group are able to acquire appropriate linguistic capital and vice versa. This leads to cultural reproduction of advantage or disadvantage respectively. Arguably, Bourdieu's thesis was limited to monoglossic societies (such as France) where social membership gives rise to variations in dialect. However, Bourdieu's theory can still be usefully applied to multilingual societies where one language dominates as the prestige language, for example, English as a high-status language in post-colonial societies, with local languages relegated to those with lower status (Pennycook, 2001:39). Following a Bourdieuan analysis, proficiency in English, particularly in the key context of the school, represents greater linguistic capital where other languages are the L1s of ESL learners.

The above discussion indicates the usefulness of Bourdieu's theory in analysing cultural reproduction through schooling in linguistically diverse settings. A considerable number of authors have expanded Bourdieu's theory of social, cultural and linguistic capital and its impact on school outcomes (Prado, 2009; Ricento, 2005; Tratamonte \& Wiliams, 2010). Albeit without particular reference to linguistic capital, we have included here a brief overview of the work of the American sociologist, Coleman (1988:95), who distinguished between the different types of social capital provided by the home and by the school in children's socialisation and learning. One category of inputs, opportunities, demands and rewards comes from schools. The second category of inputs comes from the child's closer, more intimate and more persistent environment. These inputs can be loosely described as attitudes, effort, and conception of self, which is instilled mainly by the social environment of the home (Coleman, 1988:97). In terms of schools, some schools are richer in social capital than others, depending on, among other factors, the prevailing school culture and the strength of networks formed among teachers and between teachers and other stakeholders. High levels of social capital in the school will strengthen its intellectual capital and this, in turn, benefits learners (Lin, 2012; Putnam, 2000). Conversely, ineffective schools with weak social capital undermine learner achievement and perpetuate mediocrity. Coleman (1988:98) applied the same theory to family environments. Here, we argue that the social capital of home and school, as referred to by Coleman (1988), implicitly includes linguistic capital, as illustrated by the motivation to acquire language, the material enrichment of the literacy environment through resources and the engagement of social networks to benefit language development.

Endorsing the argument on the contribution of social capital by the school, Stanton-Salazar and Fornbusch (1995:121) reported how teachers with the desired types of cultural (and thus linguistic) capital in a school can transform this capital into instrumental relations or 
institutional agents who can access and transfer valuable resources to learners, furthering their success in the school. Building on Coleman's work, other researchers (Putnam, 2000; Lin, 2010) have extended the idea of social capital to that embedded in the community, which also offers benefits to the child beyond the immediate family or school context. Sun (1998:432) found that advantaged families living in good areas experience a dual advantage, firstly, from their own well-being, and secondly, from that of the neighbourhood and the social structures found therein. In particular, Sun's (1998) study showed that this community effect could be seen in children's reading performance. In response to debates as to what is most influential, social and cultural capital embodied in the family, in the school, or in the community, Halpern (2005:157) concluded that their effects are additive. The more capital provided by family or school or community, the greater the benefit to children's learning. To narrow this down to the focus of this article, the greater the linguistic capital provided by family, the school and/or the community, the greater the positive impact on language acquisition and concomitant school performance.

\section{Rural schooling and social and cultural capital}

Adding to the above discussion, we briefly remark on factors influencing rural schooling and their implications for learners' accumulation of social and linguistic capital. Almost half of South African learners dwell in rural areas, where educational underachievement is a najor component of the cycle of disadvantage (Human Sciences Research Council \& Education Policy Consortium, 2005). Rural learners frequently attend poorly resourced schools, located in isolated areas, with high levels of poverty, disease and unemployment (HSRC, 200538). Rural communities are marked by a lack of economic capital (access to economic resources and poor employment opportunities, particularly for high-level, well-paid employment), limited access to social capital (in the form of social, medical and legal networks, among others) and restricted access to cultural capital (in the form of community-based resources commonly found in urban areas, such as internet cafes, libraries, educational centres and museums) (Maynard \& Howley, 1997). Moreover, the home social capital, defined as transmission of parental attitudes and knowledge, needed to succeed in school is thin: poorly educated rural parents are less inclined to recognise any financial benefits from their offspring's regular school attendance or academic success (Halpern, 2005:142).

In terms of English proficiency as an important component of cultural capital, parents, teachers and learners in rural areas lack sufficient exposure to English in the broader community as well as the opportunity to practise English. Parents may indeed appreciate the value of learning English as a prerequisite for socio-economic mobility (Chimbutane 2011:18), but English, in effect, functions largely as a foreign language in rural areas (English is primarily an urban language in South Africa) (Reagan, 2009). Moreover, parents who do not speak English at home may feel alienated from the school system. Television and radio often provide the only opportunities for the families to hear English, and the formal classroom is the primary context in which learners typically speak, read and write in English. Reading materials are limited to textbooks, and in many schools, learners have few opportunities to access these; moreover, school libraries are extremely rare (Chisholm, 2005:238). Consequently, an immersive English-speaking environment and linguistically proficient role models are absent in most rural settings in South Africa. The potential of reinforcement of English outside of the school is limited or lacking altogether. Bourdieu, Passeron and de Saint Martin's (1994) finding is pertinent to this situation: the social background of students affects their capacity to understand the language used in the classroom. However, language-in-education 
policymakers and educators continue to overestimate the success of the educational process, having only a 'faint idea of the insurmountable contradictions faced by a pedagogic action' (Bourdieu et al., 1994:12) which neglects to recognise the role played by the learners' linguistic and cultural context.

\section{RESEARCH DESIGN}

In light of the above, the following research question was formulated: What is the English reading performance of Grade 7 ESL learners using English as the LoLT in different types of rural primary schools? The research question was investigated by an inquiry into the English reading performance of all Grade 7 ESL learners in different types of primary school in a rural setting in Limpopo, using standardised testing.

\section{The sample}

The sample comprised all Grade 7 learners who are Xitsonga L1 speakers in four selected rural primary schools $(n=140)$ in Limpopo Province. Permission for fieldwork was granted by the respective principals and the Limpopo Department of Education. A brief description of the schools ensues; in all cases, a pseudonym has been used for purposes of confidentiality. The sample comprised 31 learners from Forest Primary, 23 learners from Maxima College, 42 learners from Debengeni Primary, and 44 learners from Tsakani Primary. The schools, situated in the Letsitele area of the Limpopo Province, were chosen as research sites by maximum variation sampling (McMillan \& Schumacher, 2001:402). According to Terre Blanche (2002:382), when using maximum variation sampling, the researcher seeks to obtain the broadest range of information and perspectives on the subject of study, resulting in the selection of participants who have had different experiences of a phenomenon, in this case, learners' reading performance in three different types of school: former model C, independent, and village schools. Notwithstanding their differences, the schools still share certain features by virtue of their distance from the English-using urban areas of the country. In all these schools, learners use their L1, in this case, Xitsonga, as the LoLT from Grade 1 to Grade 3, during which time English is introduced as an additional language. In Grade 4, these learners transfer to English as LoLT and Xitsonga is taught as an additional language. In all the schools, the typical ESL learner has had little or no contact with English outside the school setting and, more particularly, outside formal English lessons in school.

Maxima College is an independent, profit-based school established after 1994 and situated in the Letsitele area, about $15 \mathrm{~km}$ from the nearest large town. The school has a small enrolment of white learners; most learners are black children from the surrounding area. Teachers are experienced and professionally qualified. The teacher responsible for Xitsonga instruction is a Xitsonga L1 speaker and the teacher responsible for English is an English L1 speaker. The remaining staff are Afrikaans L1 speakers who can be regarded as equally proficient in English and Afrikaans. As a primarily commercial undertaking, the school does not enjoy strong community links. Extramural activities are limited and there is no after-school care. The school is adequately resourced with textbooks, a library and print-enriched classrooms. School fees are approximately R850 per month.

Forest Primary is a well-resourced former model C school situated in the Letsitele area about $25 \mathrm{~km}$ from Tzaneen, the nearest town. Prior to 1994, it served white learners from the surrounding farming community but has since become increasingly multicultural. Most black learners hail from the neighbouring black settlements. As is the case at Maxima, teachers are 
professionally qualified. The teacher responsible for Xitsonga instruction is a Xitsonga L1 speaker and the teacher responsible for English is an English L1 speaker. The remaining staff are Afrikaans L1 speakers who can be regarded as equally proficient in English and Afrikaans. As a school established before 1994, the school enjoys strong links with the surrounding community and is able to access additional resources as a result. A wide variety of extra-mural activities is available and an after-care centre offers the opportunity of homework and play under supervision. Classrooms are print-enriched with adequate textbooks and displays of learners' work. The school has its own library. School fees are approximately R530 per month.

Debengeni Primary and Tkasani Primary are higher primary schools, commencing with Grade 4, situated in two impoverished rural villages in the Letsitele area. Debengeni Primary is situated about $45 \mathrm{~km}$ from the nearest town; Tsakani Primary about $52 \mathrm{~km}$ from the same town. Teachers are professionally qualified; all learners and teachers are L1 Xitsonga speakers. Extramural activities are very limited and there is no after-care centre. Links with the community are limited, and the schools are unable to access additional resources because of the generally impoverished state of the homes and community. The schools are poorly resourced and classrooms lack teaching aids and textbooks. There are no libraries. Neither school levies school fees.

\section{Data gathering and analysis}

Data were gathered by means of the Reading Performance Test in English (Intermediate Level) as developed by the Human Sciences Research Council (HSRC) (Chamberlain \& Reinecke, 1992). This is a standardised test aimed at determining the testee's English reading performance in the Intermediate Phase. This test, which is the only standardised language test available in South Africa for this purpose at present, is applicable to L1 and L2 speakers, although different norms apply to these groups. To write the Reading Performance Test, a candidate is supplied with a test booklet, an answer sheet, a pencil and an eraser. The reading performance test is made up of multiple-choice questions from different reading texts dealing with everyday situations, and learners are expected to choose the correct answer. The Reading Performance Test in English has two components: comprehension (Q1-12, 14; 15; 17; 21; 22; $26-29 ; 31)$ and grammar (Q 13; 16; 18-20; 23-25; 32-40). The comprehension component has a maximum possible score of 22 and the grammar component has a maximum possible score of 18. The test manual does not give any indication of what is considered to be a pass mark, as performance depends on the context in which the test is written. However, $40 \%$ (a raw score of 16 out of the possible score of 40) is given as a guideline for the overall reading performance test, 8.8 out of 22 is given as a guideline pass mark for the comprehension component of the test, and 7.2 out of 18 is given as a guideline pass mark for the grammar component of the test. This guideline was used in the inquiry and allowed for comparison of results. Furthermore, the reading performance test has a reliability coefficient of 0.89 (Chamberlain \& Reinecke, 1992:18). For this kind of test, a reliability coefficient of 0.8 or higher can be regarded as satisfactory. Regarding test validity, the items of the test were accepted by a committee of subject experts after a specification table had been drawn up and a thorough study had been made of the suitability of the items to test reading performance (Bernard \& Reinecke, 1992:21). With regard to the issue of possible cultural bias, the test deals with topics of everyday occurrences at home and at school. Finally, the tests were scored by the researcher and, thereafter, an expert statistician used an SSPS statistical package to obtain descriptive statistics from the raw data. 


\section{FINDINGS}

A total of 140 learners from the four schools wrote the Reading Performance Test in English. The results are presented according to the scores for the comprehension component $(\mathrm{Q} 1-12$, $14 ; 15 ; 17 ; 21 ; 22 ; 26-29 ; 31)$ and for the grammar component (Q 13; 16; 18-20; 23-25; 3240). The comprehension component has a maximum possible score of 22 and the grammar component has a maximum possible score of 18. Results are displayed separately for each of the four schools.

Figure 1 gives the tabulated results of the comprehension component for Maxima College.

\section{Figure 1: Reading comprehension component for Maxima College}

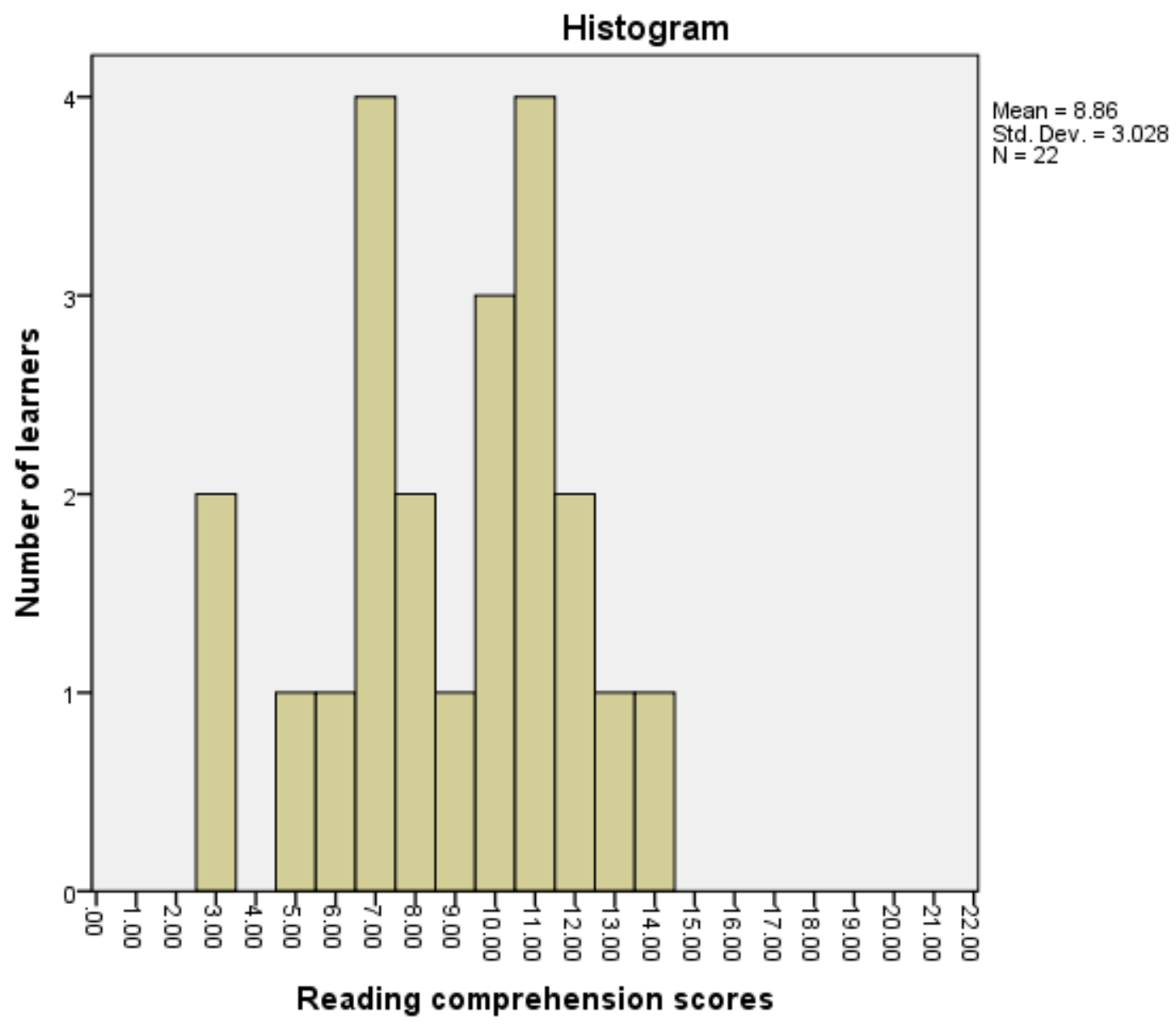

The comprehension component had possible scores that ranged from 0 to 22 . The minimum score obtained was 3 out of 22 (2 learners), whilst the maximum score was 14 out of 22 (1 learner). The average of the comprehension component was 8.86, with a median of 9.5. Since the mean is less than the median, the data are negatively skewed. The average is very close to the $40 \%$ pass mark ( 8.8 out of 22 ). This indicates that more than half of the learners (12 learners) performed above the pass mark. Conversely, $45.5 \%$ of the learners failed the component. The standard deviation was 3.028 , with a coefficient of variation of $34.2 \%$. The data are bimodal, as evidenced by the highest peaks of scores of 7 and 11 respectively, as illustrated in Figure 1. 
Figure 2: Grammar component for Maxima College

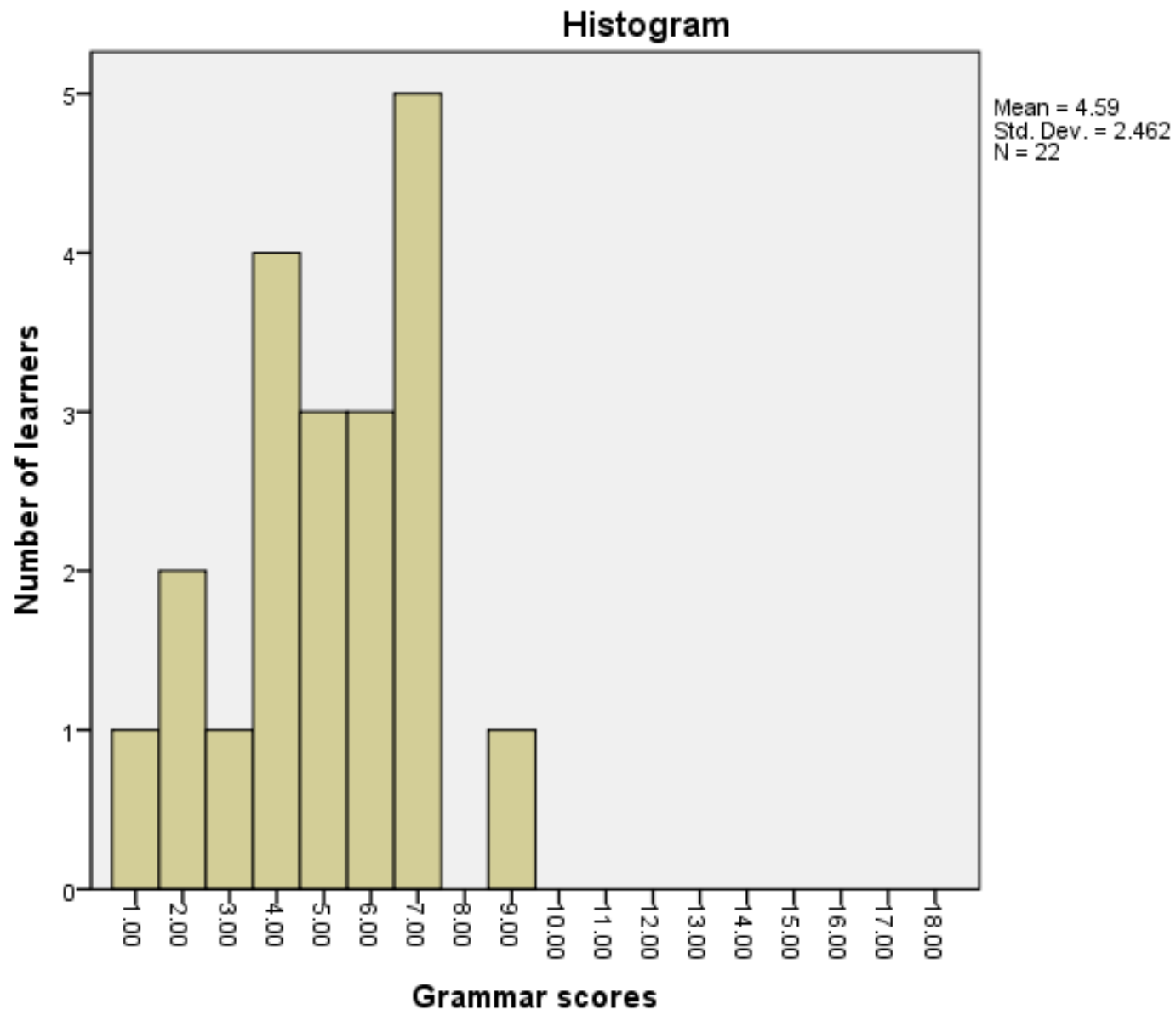

The grammar component had possible scores that ranged from 0 to 18 . The minimum score obtained was 0 out of 18 ( 2 learners) whilst the maximum score was 9 out of 18 (1 learner). The average of the grammar component was 4.59 , with a median of 5 . Since the mean is almost the same as the median, the data are almost symmetrical. The average is below the $40 \%$ pass mark (7.2 out of 18). This indicates that all but one learner $(95.5 \%)$ failed the component. The standard deviation was 2.462 , with a coefficient of variation of $53.6 \%$. The majority of the learners, that is, $68.2 \%$ (15 learners), had scores that ranged from 4 to 7 , which indicate poor performance, as depicted in Figure 2. 
Figure 3: Reading comprehension component for Forest Primary

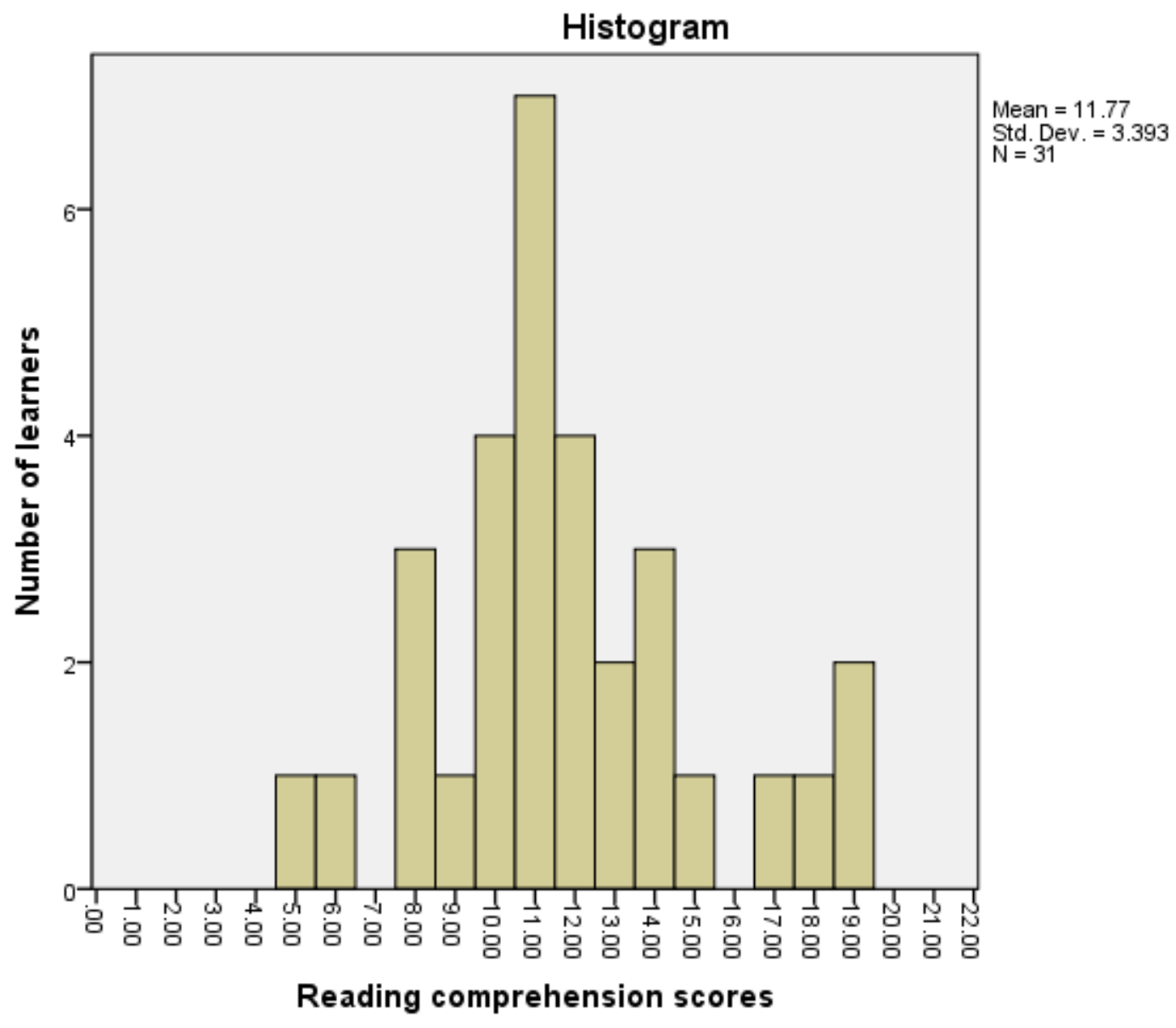

The comprehension component had possible scores that ranged from 0 to 22 . The minimum score was 5 out of 22 ( 1 learner) whilst the maximum score was 19 out 22 ( 2 learners). The average of the reading comprehension component was 11.77 , with a median of 11 . Since the mean is slightly greater than the median, data are slightly positively skewed. The learners' average is above the $40 \%$ pass mark ( 8.8 out of 22 ). Thus, only $16.1 \%$ of the learners (5 learners) failed the comprehension component; most learners performed well above the pass mark. The standard deviation was 3.393 , with a coefficient of variation of $28.8 \%$. The modal was 11 , that is, the most occurring score. The modal mark is shown by the highest peak of 11 in Figure 3. 
Figure 4: Grammar component for Forest Primary

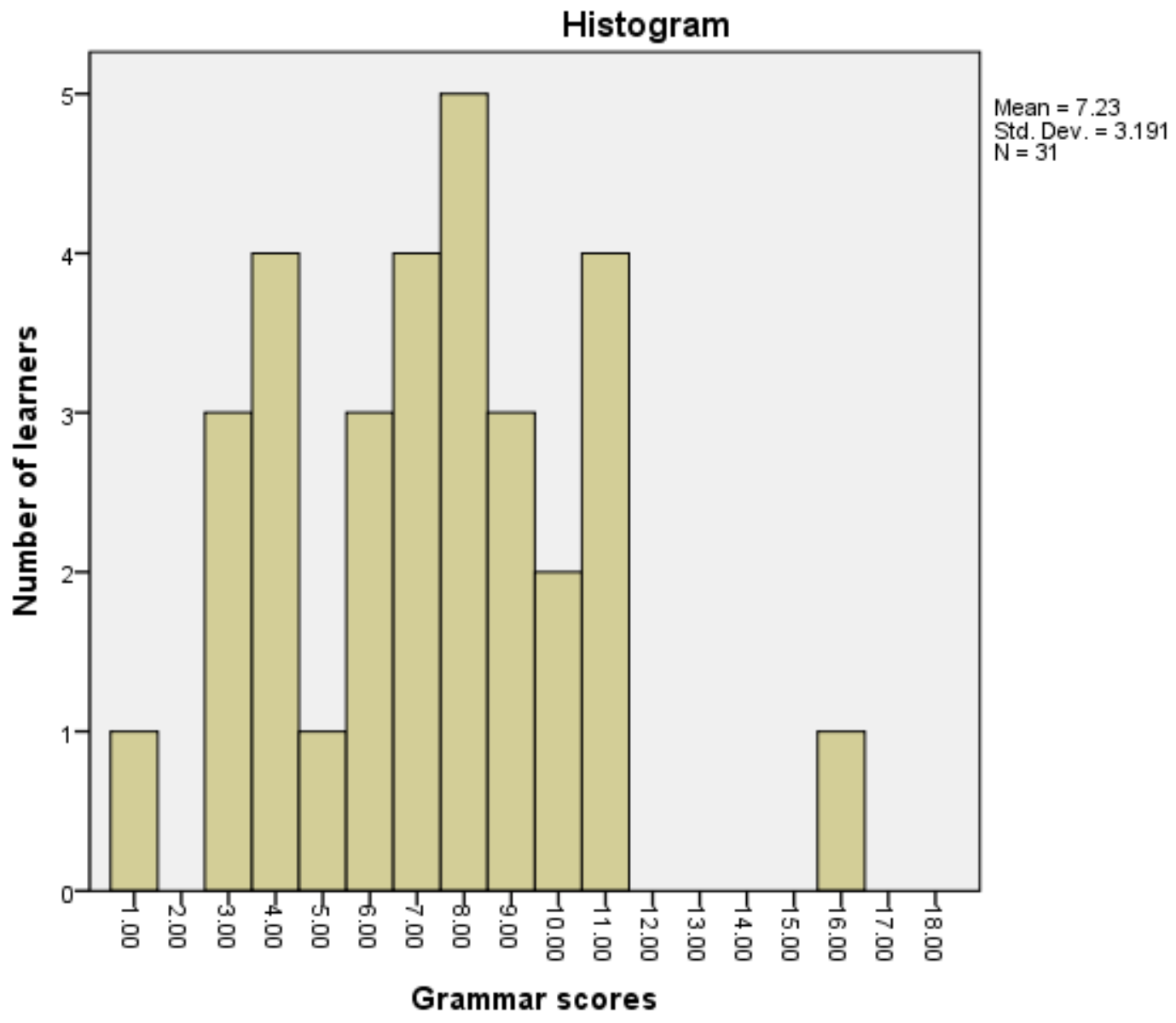

The grammar component had possible scores that ranged from 0 to 18 . The minimum score was 1 out of 18 ( 1 learner) whilst the maximum score was 16 out of 18 (1 learner). The average of the grammar component was 7.23 , with a median of 7 . Since the mean is greater than the median, the data are slightly positively skewed. The average mark is close to the $40 \%$ pass mark (7.2 out of 18). Thus, $51.6 \%$ of the learners scored below the $40 \%$ pass mark. The standard deviation of the learners was 3.191, with a coefficient of variation of $44.2 \%$. The modal mark was 8 , as shown by the highest peak of in Figure 4.

Figure 5 gives the tabulated results of the comprehension component for Debengeni Primary. 
Figure 5: Reading comprehension component for Debengeni Primary

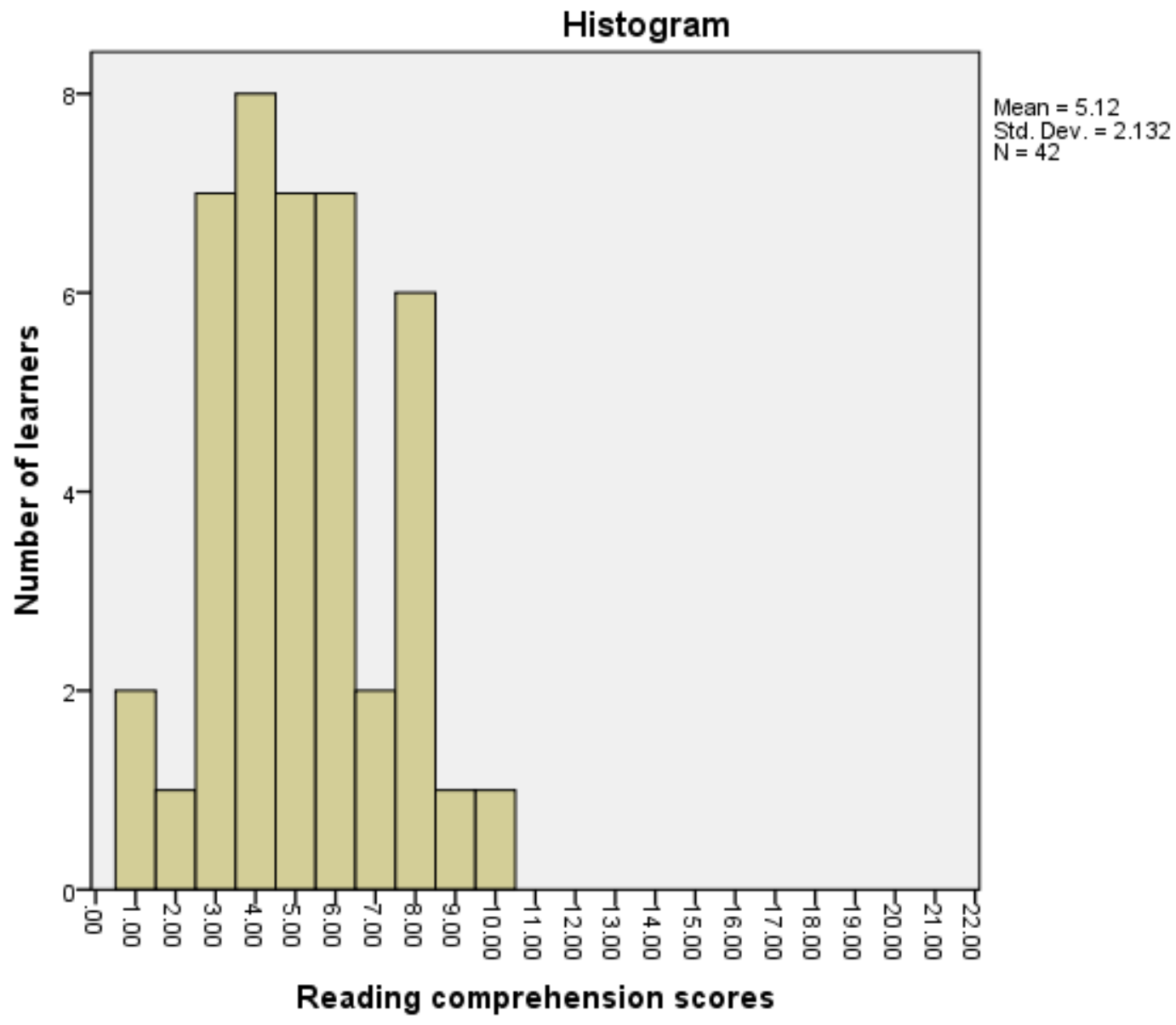

The comprehension component had possible scores that range from 0 to 22 . The minimum score was 1 out of 22 ( 2 learners) whilst the maximum score was 10 out of 22 ( 1 learner). The average of the comprehension component was 5.12, with a median of 5. Since the mean is almost the same as the median, the data seem to be almost symmetrical. The average is below the $40 \%$ pass mark ( 8.8 out of 22 ). This indicates that most of the learners failed the comprehension component. This is evidenced by the fact that 40 out of 42 learners, that is, $95.2 \%$, performed below the $40 \%$ pass mark. The standard deviation was 2.132 with a coefficient of variation of $41.7 \%$. The modal score was 4 and most scores ranged from 3 to 6 , as demonstrated in Figure 5.

Figure 6 gives the tabulated results of the grammar component for Debengeni Primary. 
Figure 6: Grammar component for Debengeni Primary

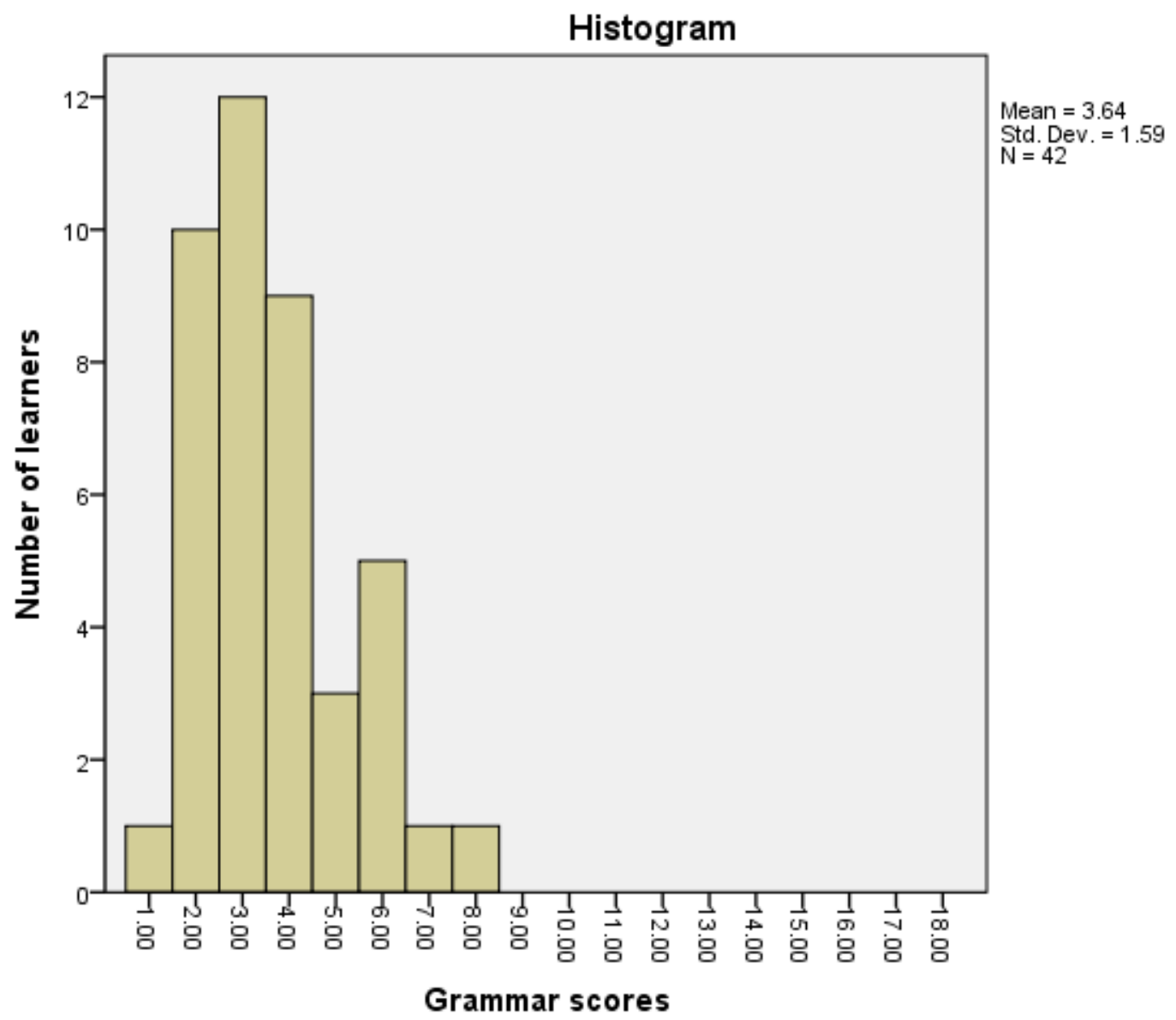

The grammar component had possible scores that ranged from 0 to 18 . The minimum score was 1 out of 18 ( 1 learner) whilst the maximum score was 8 out of 18 (1 learner). The average of the grammar component was 3.64, with a median of 3 . Since the mean is almost the same as the median, the data are almost symmetrical. The data are slightly positively skewed since the mean is greater than the median. The average is below the $40 \%$ pass mark (7.2 out of 18). This indicates that the majority of the learners (97.6\%) performed below the $40 \%$ pass mark. The standard deviation was 1.59 , with a coefficient of variation of $43.6 \%$. The modal mark was 3, as can be seen by the height peak in Figure 6.

Figure 7 gives the tabulated results of the comprehension component for Tsakani Primary. 


\section{Figure 7: Reading comprehension component for Tsakani Primary}

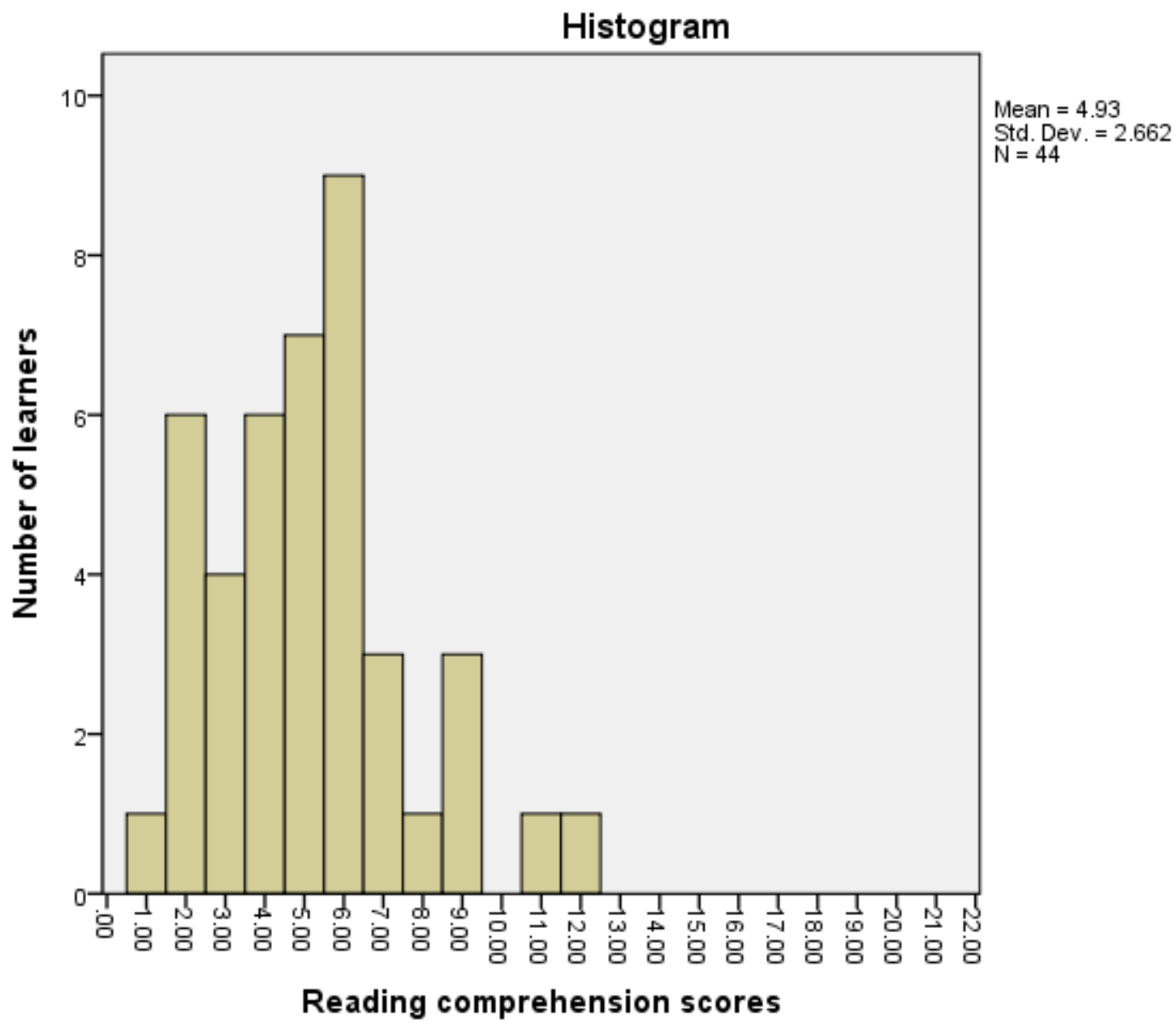

The possible scores for the comprehension component ranged from 0 to 22 . The minimum score was 0 out of 22 ( 2 learners) whilst the maximum score was 12 out of 22 ( 1 learner). The average for the comprehension component was 4.93, with a median of 5. Since the mean was almost equal to the median, the data are almost symmetrical. The average is far below the $40 \%$ pass mark ( 8.8 out of 22 ). This indicates that few learners did very well and this is supported by the fact that only $11.4 \%$ ( 5 learners) achieved scores above the $40 \%$ pass mark. The standard deviation was 2.662 , with a coefficient of variation of $54 \%$. The majority of the learners, that is, $87 \%$ (37 learners), had scores that ranged from 2 to 7 , which indicates poor performance. The modal mark was 6 , as evidenced by the highest peak in Figure 7.

Figure 8 gives the tabulated results of the grammar component for Tsakani Primary. 
Figure 8 Grammar component for Tsakani Primary

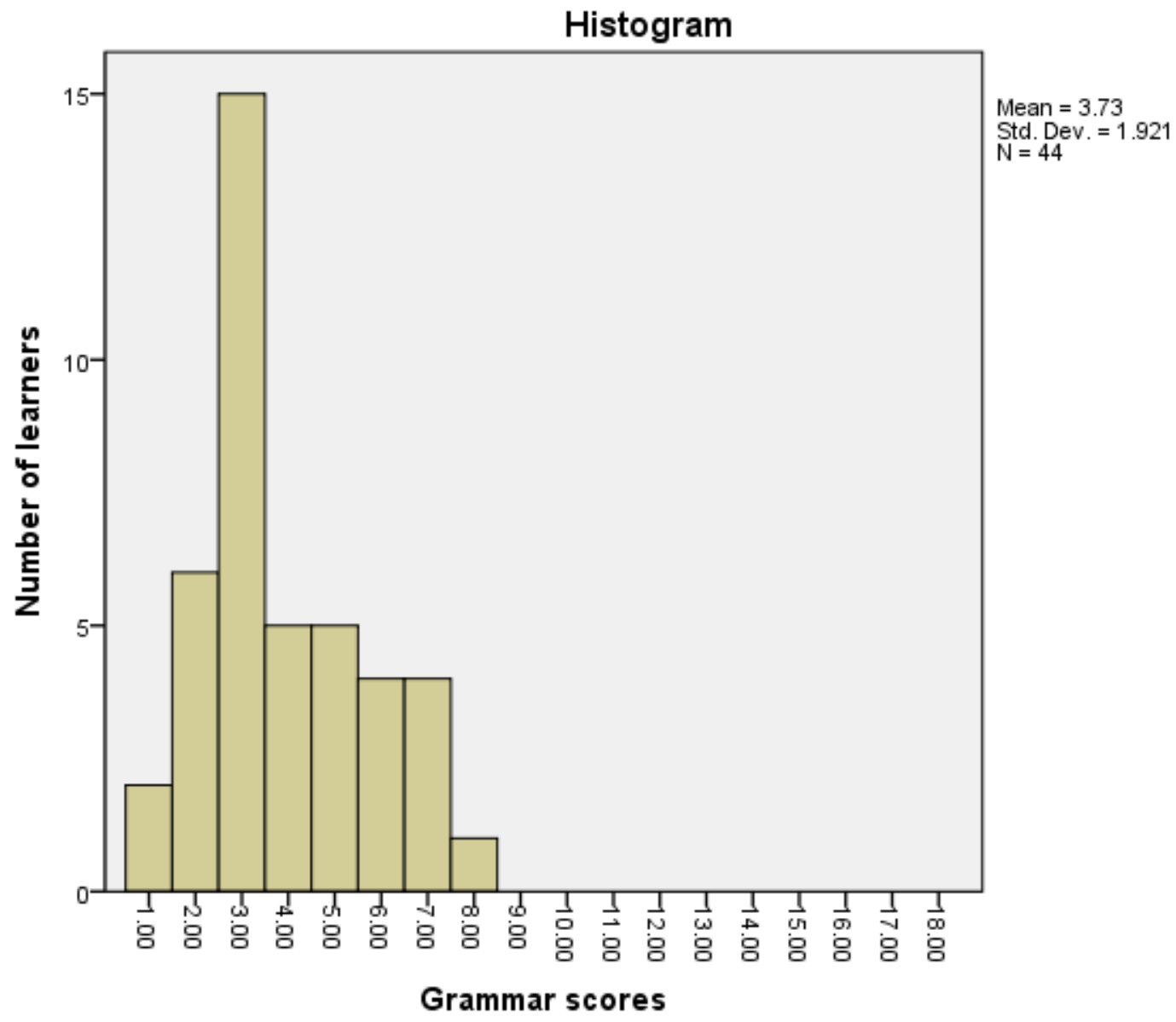

The grammar component had possible scores that ranged from 0 to 18 . The minimum score was 0 out of 18 ( 2 learners) whilst the maximum was 8 out of 18 (1 learner). The average of the grammar component was 3.73, with a median of 3 . Since the average is greater than the median, the data are positively skewed. This indicates that few learners did well. The majority of the learners, that is, over $97.7 \%$ (43 learners), scored below the $40 \%$ pass mark (which is equivalent to 7.2 out of a maximum possible score of 18), and thus, only $2.3 \%$ (1 learner) of the learners passed. The standard deviation was 1.921, with a coefficient of variation of $51.5 \%$. The majority, that is, $70.5 \%$ (31 learners), had scores that ranged from 2 to 5 , which indicate poor performance. The modal mark was 3 , as shown by the highest peak in Figure 8 . Figure 9 provides the means of the overall reading performance test results for all schools. The scores for Debengeni and Tsakani Primary schools were combined because of their strong similarity as public higher primary schools situated in villages. Moreover, the learners' performance (Figures 5-8) from these two schools is almost identical. 


\section{Figure 9 Means of overall reading performance test results for the schools}

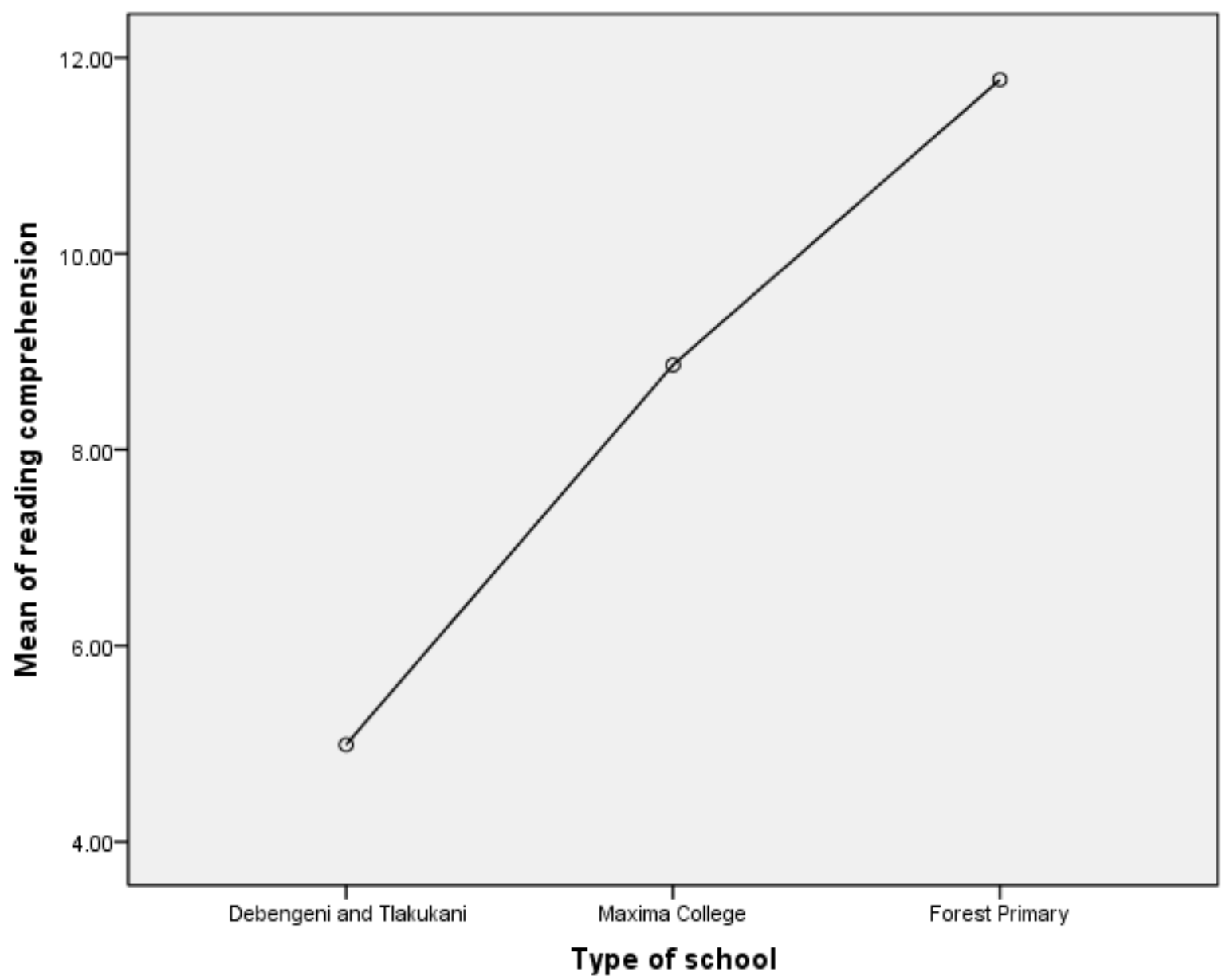

Figure 9 indicates that in overall reading performance in English, learners from Forest Primary, the former model $\mathrm{C}$ school, performed the best. The mean score was 19, which is above the $40 \%$ pass mark (16 out of 40 ). The combined performance of learners from Debengeni and Tsakani (public village schools) and the learners from Maxima College, the independent school, had mean scores of 8.74 and 13.45 respectively, which are below the $40 \%$ pass mark ( 16 out of 40 ). The hypothesis of equality of means was rejected $(F=79.050$ and $p$-value $=0.000)$.

\section{DISCUSSION}

The Forest Primary learners performed better in both reading comprehension (Figure 3) and grammar (Figure 4) than the learners from the other two types of schools (independent and village schools). Interestingly, learners showed poorer performance in the grammar component (mean 7.23) than in the comprehension component (mean 11.77), a pattern repeated in all schools in the study. At Forest Primary, only a 5\% difference was observed between the grammar and the comprehension component results.

The Maxima learners lagged behind Forest Primary in both reading comprehension (Figure 1) and grammar (Figure 2) although they still performed better than learners from Debengeni and Tsakani combined. Similarly to Forest Primary, the learners showed poorer performance in the grammar component (mean 4.59) than the comprehension component (mean 8.86). At 
Maxima Primary, there was only a $4 \%$ difference between the grammar and the comprehension component results.

The Debengeni learners lagged behind the former-model C (Forest Primary) and the independent school (Maxima) in both reading comprehension (Figure 5) and grammar (Figure 6). The learners showed poorer performance in the grammar component (mean 3.64) than the comprehension component (mean 5.12). However, at Debengeni Primary, there was only a $2 \%$ difference between the grammar and the comprehension component results. The Tsakani learners showed the worst performance, when compared to the other schools, in both reading comprehension (Figure 6) and grammar (Figure 7). The learners showed poorer performance in the grammar component (mean 3.73) than the comprehension component (mean 4.93). Although Debengeni showed a slightly better performance in both components of the test, the reading performance in English for the village schools in grammar and comprehension was observed to be very poor.

To give a view of the overall reading performance in English, the LoLT which learners use to master academic content in all learning areas and the mean scores of the reading and grammar components were combined (Figure 9) to show the results from the different types of school. As mentioned earlier, the Debengeni and Tsakani scores were combined due to the similarity in their setting and performance. Figure 9 indicates that the overall mean score for Forest Primary was considerably higher than that obtained by the learners in the other types of schools. In fact, learners obtained a mean score of 19 which is 3 points above a pass mark (16 out of 40). This performance bodes well for the learners' effective use of English as LoLT to master academic content in all learning areas.

In contrast, Figure 9 indicates that the overall mean score for Maxima College was only 13.45, which is below the pass mark (16 out of 40). This performance suggests that these learners still lack adequate proficiency in English to use it effectively as a LoLT for mastery of academic content in all learning areas. Finally, Figure 9 indicates that the overall mean score for Debengeni and Tsakani combined was only 8.2, which is far below the pass mark (16 out of 40). This finding indicates an even greater lack of English proficiency amongst the learners when compared to those at Maxima and suggests that the possibility that they are able to access academic content in all learning areas through English as the LoLT is doubtful.

\section{CONCLUSION}

The findings suggest that the type of school has implications for the acquisition of English language proficiency of ESL learners in a rural setting. As has been pointed out in the literature review, using a common LoLT does not mean that linguistic capital is equally distributed throughout a schooling system. Many ESL learners come from homes which seldom provide literacy practices in English. Their acquisition of English proficiency is therefore more dependent on the quality of linguistic resources provided by the teaching staff and the general school and community environment. At the same time, however, all families possess important linguistic capital in their L1, and parents should be informed by the school through workshops, talks and parent meetings about strategies to create a linguistically enriched environment in the home using the mother tongue. For example, parents can converse with their children about everyday topics and events during shopping trips, visits to church or sports events and travelling to school and work; read or tell stories to children; use magazines, newspapers and comics in L1 to stimulate discussion in the home, where books in L1 are not freely available; and discuss schoolwork in the L1. 
In the former-model $\mathrm{C}$ school, ESL learners have been exposed to a multicultural setting in which English is not strictly confined to formal classroom use. These learners have some opportunity to interact with English L1 learners in other areas of school life beyond the classroom. Bilingual teachers can also offer a rich source of language knowledge, not exclusively limited to English. Moreover, as the former model $\mathrm{C}$ school has a history of engagement with the community prior to 1994, staff and parents possess sources of capital which they can transform into both physical resources or social networks that can be used to transfer valuable linguistic capital to ESL learners, which may benefit their school success (Stanton-Salazar \& Fornbusch, 1995:121). To a certain extent, the independent school shares in some of these advantages. However, as a more recently established school, which operates on a profit-basis, it lacks the same cohesion with the community and thus its access to social capital, as embodied in community networks, is more limited. Both this school and the village schools should endeavour to identify and make use of the capital embedded in the expertise available in the community. Social services, the police, the health clinic, sports clubs and religious institutions, to mention but a few, are all sources of rich capital, including linguistic capital. Community organisations can be invited to address learners about relevant topics, using both L1 and L2. They can provide L1 language teaching materials, such as, books, newspapers and magazines. Community members can be invited to tell stories and share oral history with children in L2. Inputs in both L1 and L2 will serve to strengthen language learning. These recommendations are of particular importance to the village schools, which have the greatest lack of funds of language knowledge, teaching aids and books, as well as social networks which could benefit learners.

Thus, the overall findings suggest that the type of school can act as an agent of cultural reproduction (Bourdieu, 1991). One school type and its concomitant access to cultural capital may privilege ESL learners and promote their academic success; conversely, another school type with limited sources of cultural capital may perpetuate disadvantage among ESL learners. However, by implementing the strategies of parent and community involvement suggested above, school capital can be enriched. Furthermore, attention should be given through in-service training to improve the English language proficiency of teachers who are speakers of indigenous African languages. Finally, all teachers, irrespective of language background, should be made aware of their own linguistic capital and of theories of language acquisition which stress the interrelationship between L1 and L2. All teachers should be encouraged to coach literacy skills, not only in the formal language class but across the curriculum. 


\section{REFERENCES}

BERNARD, I \& S REINECKE. 1992. English writing performance test. Intermediate level. Pretoria, RSA: Human Sciences Research Council.

BOURDIEU, P. 1973. Cultural reproduction and social reproduction. In Brown, R (Ed). Knowledge, education and cultural change. New York, NY: Doubleday.

BOURDIEU, P. 1986. The forms of capital, In Richardson, JG (Ed). Handbook of theory and research for the sociology in education. Westport, CT: Greenwood Press.

BOURDIEU, P. 1991. Language and symbolic power. New York, NY: Polity Press.

BOURDIEU, P., J-C PASSERON \& M DE SAINT MARTIN. 1994. Students and the language of teaching. In Academic discourse: Linguistic understanding and professorial power. Stanford, CA: Stanford University Press.

CHAMBERLAIN, JC \& S REINECKE. 1992. Manual: Proficiency test English second language intermediate level. Pretoria, RSA: Human Sciences Research Council.

CHIMBUTANE, F. 2011. Rethinking bilingual education in postcolonial context. Clevedon, UK: Mulitilingual Matters,

CHISHOLM, L. 2005. The state of South African schools. In Daniel, J., R Southall \& J Lutchman (Eds). State of the nation: South Africa 2004-2005. Cape Town, RSA: HSRC Press.

CHRISTIE, P. 2008. Opening the doors of learning: Changing schools in South Africa. Cape Town, RSA: Heinemann.

COLEMAN, JS. 1987. Social capital in the creation of human capital. American Journal of Sociology, 94:95-120.

COLEMAN, JS.1988. The creation and destruction of social capital. Journal of Law, Ethics and Public Policy, 3:375-404.

COLEMAN, JS. 1995. Family, school and home capital. In Husen, T \& TN Postlethwaite (Eds). International Encyclopedia of Education. (2 $2^{\text {nd }}$ ed.) Oxford. UK: Pergamon Press.

Department of Education, 1997, Language in education policy. Pretoria, RSA. Accessed 30 November 2010 from http://www.education.gov.za/Documents/policies/LanguageEducationPolicy1997.pdf

DEPARTMENT OF BASIC EDUCATION, 2010. Annual national assessment 2011. A guideline for the interpretation and use of ANA results. Pretoria,RSA: Department of Basic Education.

FISHMAN, J. 1997. Maintaining languages. What works and what doesn't. In Cantoni, G (Ed.). Stabilizing indigenous anguages. Flagstaff, AZ.: Northern Arizona Press.

HALPERN, D. 2005. Social capital. Cambridge: Polity Press.

HEUGH, K. 2000. The case against bilingual and multilingual education in South Africa. Occasional Paper no. 6. Cape Town, RSA: PREASA.

HEUGH, K. 2002. The case against bilingual and multilingual education in South Africa. Perspectives in Education 20(1):59-77. 
HEUGH, K. 2005. Mother tongue education is best. HSRC Review 3(3):1-3.

HEUGH, K. 2008. Language policy and education in Southern Africa. In May, W \& NH Hornberger (Eds.). Encyclopedia of language and education: vol 1, pp.355 -367.

HOWIE, SJ. 2008. A historical overview of the IEA's language-related studies leading to the implementation of the Progress in International Reading Literacy Studies. In Howie, S.J \& T Plomp. Reading achievement: International perspectives, from IEA's Progress in International Reading Literacy Studies (PIRLS). Education Research and Evaluation, 14(6): $477-487$.

HUMAN SCIENCES RESEARCH COUNCIL \& EDUCATION POLICY CONSORTIUM, 2005. Emerging voices: a report on Education in South African Rural Communities. Pretoria, RSA: HSRC.

INTERNATIONAL ASSOCIATION FOR THE EVALUATION OF EDUCATIONAL ACHIEVEMENT 2006. PRLS 2006 International Report. Accessed 20 June 2009, from http://timss.bc.edu/PDF/p06 international report.pdf.

LIN, N. 2012. Beyond getting in and fitting in: An examination of social networks and professionally relevant social capital among Latina/o university students. Journal of Hispanic Higher education. 11:179-196.

MACDONALD, C. 1990. Crossing the threshold into standard three in black education: The consolidated main report of the Threshold Project. Pretoria, RSA: HSRC Press.

MACDONALD, C. 1991. Eager to talk and learn and think: Bilingual primary school education in South Africa. Cape Town, RSA: Maskew Miller.

MACDONALD, C. 2006. The properties of mediated action in three different literacy contexts in South Africa. Theory and Psychology, 16(1):51-80.

MAYNARD, S \& A HOWLEY. 1997. Parent and community involvement in rural schools. Accessed 1 July 2005. Eric Digest [ED408143]. http:acclaim.coe.ohiou.educ

McMILLAN, JH \& S SCHUMACHER. 2001. Research in education: A conceptual introduction (4th ed.). London, UK: Harper \& Collins.

MOLOI, M. \& J STRAUSS. 2005. The SACMEQ11 Project in South Africa: A study of the conditions of schooling and quality of education. Harare, ZIM: SACMEQ.

OVANDO, CJ \& P McLAREN. 1999. The politics of multilingualism and bilingual students and teachers caught in a crossfire. Columbus, OH: McGraw Hill.

ORMAN, J. 2008. Language policy and national-building in post-apartheid South Africa. Washington, DC: Springer.

PENNYCOOK, A. 1994. The cultural politics of English as an international language. Harlow, UK, Longman.

PRADO, JM. 2009. Comparing educational trajectories of two Chinese students and one Latin student, A social capital approach. The High School Journal, 92:14-27.

PUTNAM, RD. 2000. Bowling alone: The collapse and revival of American community. New York, NY: Simon \& Schuster.

REAGAN, TG. 2009. Language matters: Reflection on education linguistics. London, UK: Information. 
REPUBLIC OF SOUTH AFRICA (RSA) 1996(a). Constitution of the Republic of South Africa, Act No. 108 of 1996. Government Gazette Vol 378, No 17678. Pretoria, RSA: Office of the President.

REPUBLIC OF SOUTH AFRICA (RSA) 1996(b). South African Schools Act, Act No. 84 of 1996. Government Gazette, Vol 377, No 17579. Cape Town, RSA: Office of the President (no 1867).

RICENTO, T. 2005. Introduction to language policy. Malden, UK: Blackwell.

SKATNUBB-KANGAS, 2006. Linguistic human rights. In Ammon, U., N Dittmar \& K J. Mattheier (Eds.) Sociolinguistics: An international handbook of the science of language and society, Vol. 33. Berlin, Germany: De Gruyter.

STANTON-SALAZAR, R. \& FORNBUSCH, S. 1995. Social capital and the reproduction of inequality: Information networks among Mexico-origin high school students. Sociology of Education. 68(2):116-135.

SUN, Y. 1998. The academic success of East-Asian American students: An investment model. Social Science Research. 27(4):432-456.

TERRE BLANCHE, M. 2002. Research in practice: Moonstats CD \& User guide, applied methods for the social sciences. Cape Town, RSA: UCT Press.

\section{BIOGRAPHICAL NOTE}

Tintswalo Vivian Manyike is senior lecturer in the Department of Educational Studies at the University of South Africa, Her research interests include multicultural/ bilingual education, teaching English as a second language and language policy in education. (Email: manyitv@unisa.ac.za).

Eleanor Lemmer is professor in the field of Comparative Education in the Department of Further Teacher Education at the University of South Africa. Her research interests include language policy in multicultural schools in South Africa and parent involvement. (Email: lemmeem@unisa.ac.za). 